\title{
Fatty Acid Compositions of Various Tissue Lipids in the Marine Bivalves, Megangulus venulosus and Megangulus zyonoensis, from Coastal Waters of Hokkaido, Northern Japan
}

\author{
Hideki KawaShima $^{1 *}$ and Masao OHNISHI ${ }^{2}$ \\ ${ }^{I}$ Bioscience Laboratory, Miyako College Division, Iwate Prefectural University \\ (1-5-1, Ka-nan, Miyako-shi, Iwate 027-0039, JAPAN) \\ ${ }^{2}$ Department of Bioresource Science, Obihiro University of Agriculture and Veterinary Medicine \\ (Inada-cho, Obihiro-shi, Hokkaido, 080-8555, JAPAN)
}

Edited by K. Kikugawa, Tokyo Univ., Pharm. Life Sci., and accepted February 15, 2003 (received for review November 26, 2002)

\begin{abstract}
Various tissue lipids from the marine bivalves, Megangulus venulosus (M. venulosus) and Megangulus zyonoensis (M. zyonoensis), were analyzed for comparison of major fatty acids and their distribution. The main fatty acid components in this genus in all tissues were found to be 16:0 (11.0-15.2\%), 18:0 (4.1-8.6\%), 20:5n-3 (13.3-25.6\%) and 22:6n-3 (8.1-16.7\%), with n-3 polyunsaturated fatty acids most abundant. The proportion of 20:5n-3 was higher in $M$. zyonoensis than in $M$. venulosus, and 22:6n-3 was higher in M. venulosus than in M. zyonoensis. The proportions of 20:5n-3 and 22:6n-3 were highest in muscle tissue lipids from $M$. venulosus and $M$. zyonoensis, at $33.1 \%$ and $36.2 \%$, respectively. The distribution of major fatty acid components in neutral (NL) and polar lipids (PL) was determined, with 16:0 and 20:5n-3 shown for NL, and 16:0, 20:5n-3 and 22:6n-3 for PL. The proportion of 22:6n-3 in NL and PL differed significantly, 22:6n-3 being much higher in PL. The main branched fatty acid component, 4,8,12-trimethyltridecanoic acid, was found mainly in PL of viscera tissues from either species. In addition, 2-hydroxypentadecanoic, 2-hydroxyhexadecanoic and 2-hydroxyheptadecanoic acids were also found to be present in the two species and this presence of 2-hydroxy fatty acids in the genus Megangulus is reported here for the first time.
\end{abstract}

Key words: fatty acid composition, tissue lipid, bivalve, Megangulus venulosus, Megangulus zyonoensis

\section{Introduction}

The marine bivalve, Shirogai, belonging to the genus, Megangulus, is a valuable food resource, owing to its soft flesh texture, rich sweetness and good taste, especially in Japan (1). However, the production of this bivalve is showing a slightly decreasing trend from year to year. Biogenic management of Shirogai is not adequate, for the reasons are unclear so far. Its reproduc- tive cycle and environment conditions are poorly understood (2). Biochemical and physiological studies on the reproductive cycle of Shirogai have not been reported previously. But lipids have been shown to be essential to the reproductive process (3-5). Examination of lipids and fatty acids has provided some clarification of biochemical and environmental conditions for bivalve growth and distribution. Similarities and differences in fatty acids according to tissue in the leading commer-

\footnotetext{
${ }^{*}$ Correspondence to: Hideki KaWASHIMA, Bioscience Laboratory, Miyako College Division, Iwate Prefectural University,

1-5-1, Ka-nan, Miyako-shi, Iwate 027-0039, JAPAN

E-mail: ajoe@iwate-pu.ac.jp
} 
cial species, Megangulus venulosus and Megangulus zyonoensis, have not been reported. This paper presents for the first time an investigation for comparison of major fatty acids and their distribution. Basic clarification is made of specific roles of lipids and fatty acids in various organs as well as the reproductive cycle and natural environments of the two species.

\section{Materials and Methods}

The bivalves, Megangulus venulosus (M. venulosus) and Megangulus zyonoensis (M. zyonoensis), were procured from a local fish market (Tomakomai fishermen's cooperative association, Hokkaido) in March and April, 2002 and stored at $-20^{\circ} \mathrm{C}$ until needed for analysis. All tissues were suspended in a chloroform-methanol mixture $(2: 1, \mathrm{v} / \mathrm{v})$, and then homogenated for $30 \mathrm{sec}$ at $11,000 \mathrm{rpm}$ with an IKA ULTRA-TURRAX ${ }^{\circledR}$ T25 Basic (IKA Japan KK, Nara, Japan) for cell disruption. Lipids were extracted according to the method of Bligh and Dyer (6).

Fatty acid methyl esters (FAME) and dimethylacetals (DMA) were prepared with $14 \% \mathrm{BF}_{3} /$ methanol for $1 \mathrm{~h}$ at $90^{\circ} \mathrm{C}$ in a screw-capped test tube (7). FAME and DMA were purified by thin-layer chromatography (TLC) on Kieselgel 60G plates (Merck, Co., Ltd., Darmstadt, Germany) with $n$-hexane-diethyl ether $(80: 20, \mathrm{v} / \mathrm{v})$ for development. Individual lipid classes were quantified by preparative TLC. The various lipid classes were separated by TLC with $n$-hexane-diethyl ether-acetic acid $(80: 20: 1, \mathrm{v} / \mathrm{v} / \mathrm{v})$ or chloroform-methanol-water $(65: 25: 4, \mathrm{v} / \mathrm{v} / \mathrm{v})$ and the developed TLC plates were sprayed with $50 \%$ sulfuric acid solution or Dittmer reagent (8), followed by heating at $100^{\circ} \mathrm{C}$ for $10 \mathrm{~min}$. Neutral and polar lipids were separated with a mixture of chloroform-methanol $(9: 1, \mathrm{v} / \mathrm{v})$ by TLC and then recovered from the TLC plates by scraping off the corresponding spots. Percentages of neutral and polar lipids were expressed as amounts of total fatty acids in each lipid.

FAME were analyzed by gas-liquid chromatography (GC) with a Shimadzu GC-8A instrument (Shimadzu Seisakusho Co., Kyoto, Japan) equipped with a flame ionization detector and a SUPELCOWAX ${ }^{\mathrm{TM}}-10$ capillary column $(30 \mathrm{~m} \times 0.25 \mathrm{~mm}$ i.d., $0.25 \mu \mathrm{m}$ film thickness; Supelco Inc., Bellefonte, PA, USA). The column temperature was isothermal at $210^{\circ} \mathrm{C}$. The injector and detector temperatures were 250 and $260^{\circ} \mathrm{C}$, respectively. The carrier gas was helium at a flow rate of 1.0 $\mathrm{mL} / \mathrm{min}$. FAME and DMA were analyzed by gas chromatography-mass spectrometry (GC-MS) using a Hewlett-Packard Agilent 5973N MSD and Agilent 6890N GC (Hewlett-Packard, Palo Alto, CA, USA) equipped with an OMEGAWAX ${ }^{\mathrm{TM}}-320$ capillary column $(30 \mathrm{~m} \times 0.32 \mathrm{~mm}$ i.d., $0.25 \mu \mathrm{m}$ film thickness; Supelco Inc., Bellefonte, PA, USA). Column temperature was programmed as follows: isothermal at $150^{\circ} \mathrm{C}$ for $1 \mathrm{~min}$, increased from 150 to $250^{\circ} \mathrm{C}\left(10^{\circ} \mathrm{C} / \mathrm{min}\right)$ where maintained for $5 \mathrm{~min}$. All spectra were obtained at an ionization energy of $70 \mathrm{eV}$ (electron impact ionization). Analysis in all cases was conducted in duplicate with the results expressed as mean values. Most standards and reagents used in this study were purchased from Sigma Chemical Co. (St. Louis, MO, USA).

\section{Results and Discussion}

Total lipids (TL) of mantle, muscle and viscera as wet weight basis of percentage were $0.7,0.5$ and $0.8 \%$ in $M$. venulosus, and $0.6,0.6$ and $1.6 \%$ in $M$. zyonoensis, respectively (shown in Table 1). The mantle and muscle lipids for either species were mainly polar lipids (PL), and constituted $77-78 \%$ of TL. Viscera tissue from $M$. zyonoensis contained $80 \%$ neutral lipids (NL), the amount of which was greater than from

Table 1 Total Lipid Content and Proportion (\%) of Neutral and Polar Lipids in Various Tissues from Megangulus venulosus and Megangulus zyonoensis.

\begin{tabular}{lcccccc}
\hline & \multicolumn{2}{c}{ Mantle } & \multicolumn{2}{c}{ Muscle } & \multicolumn{2}{c}{ Viscera } \\
\cline { 2 - 7 } & M. venulosus & M. zyonoensis & M. venulosus & M. zyonoensis & M. venulosus & M. zyonoensis \\
\hline Total lipid (wet wt) & 0.7 & 0.6 & 0.5 & 0.6 & 0.8 & 1.6 \\
Neutral lipids* & 21.7 & 22.9 & 24.7 & 23.3 & 22.7 & 80.2 \\
Polar lipids* & 78.3 & 77.1 & 75.3 & 76.7 & 77.3 & 19.8 \\
\hline
\end{tabular}

* Value expressed as amounts of total fatty acids. 
Table 2 Fatty Acid Composition (\%) of Total Lipids in Various Tissues of Megangulus venulosus and Megangulus zyonoensis.

\begin{tabular}{|c|c|c|c|c|c|c|}
\hline \multirow{2}{*}{ Fatty Acid } & \multicolumn{2}{|c|}{ Mantle } & \multicolumn{2}{|c|}{ Muscle } & \multicolumn{2}{|c|}{ Viscera } \\
\hline & M. venulosus & M. zyonoensis & M. venulosus & M. zyonoensis & M. venulosus & M. zyonoensis \\
\hline TMTD $^{1)}$ & $<0.1$ & $<0.1$ & $<0.1$ & $<0.1$ & 1.9 & 2.2 \\
\hline phytanic acid ${ }^{2)}$ & 0.3 & 0.7 & 0.3 & 0.4 & 0.3 & 1.1 \\
\hline 2-hydroxy 15:0 & 0.6 & $<0.1$ & $<0.1$ & $<0.1$ & $\mathrm{nd}^{5)}$ & nd \\
\hline 2-hydroxy 16:0 & 2.6 & 2.1 & 1.7 & 1.7 & 1.6 & 0.4 \\
\hline 2-hydroxy 17:0 & 0.7 & $<0.1$ & 0.5 & $<0.1$ & $<0.1$ & nd \\
\hline iso $17: 0$ & 0.4 & 0.4 & 0.3 & $<0.1$ & 0.4 & $<0.1$ \\
\hline iso $18: 0$ & 0.9 & 0.8 & 0.7 & 0.6 & 0.7 & 0.5 \\
\hline iso 19:0 & 0.6 & 0.4 & 0.3 & 0.4 & 0.3 & $<0.1$ \\
\hline 14:0 & 0.7 & 1.3 & 0.9 & 1.3 & 1.2 & 4.0 \\
\hline 15:0 & 1.9 & 1.6 & 1.9 & 1.5 & 1.8 & 0.6 \\
\hline $16: 0$ & 11.0 & 14.0 & 12.5 & 15.2 & 11.0 & 12.9 \\
\hline 17:0 & 0.9 & 0.7 & 0.8 & 0.6 & 0.8 & 0.2 \\
\hline 18:0 & 8.2 & 8.4 & 8.6 & 8.4 & 8.5 & 4.1 \\
\hline 19:0 & 0.7 & 0.6 & $<0.1$ & nd & $<0.1$ & nd \\
\hline 20:0 & 0.3 & 0.3 & 0.2 & $<0.1$ & 0.3 & $<0.1$ \\
\hline $16: 1 n-7$ & 3.0 & 4.0 & 3.6 & 4.7 & 3.3 & 10.8 \\
\hline $16: 1 n-4$ and/or n-5 & 0.2 & 0.2 & 0.2 & 0.3 & 0.7 & 0.3 \\
\hline $17: 1$ & $<0.1$ & 0.6 & $<0.1$ & 0.4 & $<0.1$ & $<0.1$ \\
\hline $18: 1 \mathrm{n}-9$ & 2.5 & 2.0 & 2.2 & 1.6 & 1.9 & 1.0 \\
\hline $18: 1 n-7$ & 2.3 & 3.1 & 2.1 & 2.6 & 2.7 & 4.3 \\
\hline $20: 1 n-13$ & 3.6 & 2.4 & 3.3 & 1.6 & 2.8 & 0.8 \\
\hline 20:1n-9 & 2.1 & 2.2 & 1.6 & 2.5 & 2.1 & 1.3 \\
\hline $20: 1 n-7$ & 3.7 & 4.5 & 3.4 & 3.8 & 4.2 & 2.6 \\
\hline $18: 2 n-6$ & 0.5 & 0.5 & 0.2 & 0.5 & 0.7 & 0.5 \\
\hline $20: 2 n-6$ & 0.8 & 1.1 & 0.7 & 0.8 & 0.8 & 0.8 \\
\hline $20: 2$ & 0.3 & 0.4 & 0.3 & $<0.1$ & 0.3 & 0.5 \\
\hline $7,13-22: 2$ & 1.2 & 0.8 & 0.6 & $<0.1$ & 0.9 & $<0.1$ \\
\hline $7,15-22: 2$ & 6.3 & 4.3 & 3.3 & 2.4 & 4.7 & 1.0 \\
\hline $16: 3$ & $<0.1$ & $<0.1$ & $<0.1$ & $<0.1$ & $<0.1$ & 0.8 \\
\hline $18: 3$ & $<0.1$ & $<0.1$ & $<0.1$ & $<0.1$ & $<0.1$ & 0.6 \\
\hline $20: 3$ & 0.4 & 0.3 & 0.3 & $<0.1$ & 0.3 & $<0.1$ \\
\hline $16: 4$ & nd & $<0.1$ & nd & nd & nd & 1.8 \\
\hline $18: 4 n-3$ & 0.5 & 0.8 & 0.7 & 0.8 & $<0.1$ & 3.7 \\
\hline $20: 4 n-6$ & 6.2 & 4.3 & 4.5 & 2.6 & 4.4 & 1.3 \\
\hline $20: 4 n-3$ & 0.5 & 0.7 & 0.5 & 0.5 & 0.7 & 1.2 \\
\hline $22: 4 n-6$ & 1.7 & 1.0 & 1.2 & 0.7 & 1.3 & $<0.1$ \\
\hline $20: 5 n-3$ & 13.3 & 17.8 & 16.4 & 22.3 & 17.3 & 25.6 \\
\hline $21: 5 n-3$ & 1.0 & 1.2 & 1.6 & 1.6 & 1.7 & 1.7 \\
\hline $22: 5 n-6$ & 1.4 & 0.9 & 1.5 & 0.8 & 1.2 & $<0.1$ \\
\hline $22: 5 n-3$ & 4.5 & 3.7 & 5.2 & 5.0 & 4.1 & 1.3 \\
\hline $22: 6 n-3$ & 11.9 & 10.2 & 16.7 & 13.9 & 11.5 & 8.1 \\
\hline Unidentified ${ }^{3)}$ & 2.3 & 1.7 & 1.2 & 0.5 & 3.6 & 4.0 \\
\hline Saturated ${ }^{4)}$ & 29.5 & 30.6 & 28.4 & 29.7 & 28.5 & 24.9 \\
\hline Monoenes & 17.4 & 19.0 & 16.4 & 17.5 & 17.7 & 21.1 \\
\hline n-6 PUFA & 10.6 & 7.8 & 8.1 & 5.4 & 8.4 & 2.6 \\
\hline n-3 PUFA & 31.7 & 34.4 & 41.1 & 44.1 & 35.3 & 41.6 \\
\hline Others & 10.8 & 8.2 & 6.0 & 3.3 & 10.1 & 9.8 \\
\hline
\end{tabular}

\footnotetext{
1) 4,8,12-Trimethyltridecanoic acid.

2) Including $16: 2 \mathrm{n}-4$.

3) Each unidentified component less than $1 \%$ of total fatty acids.

4) Phytanic acid omitted from saturated fatty acids.

5) nd: not detected.
} 


\section{H. Kawashima and M. Ohnishi}

M. venulosus. The reason for this could not be determined in the present study. The difference in which lipid and/or fatty acid composition is related to the environmental conditions. Therefore, it may be clarified only through additional study. Major NL and PL were found to be triaclyglycerol and sterol, and phosphatidylethanolamine (PE) and phosphatidylcholine (PC) for both species, based on TLC comparison of authentic standards.

Predominant fatty acids in TL of various tissues were 16:0 (11.0-15.2\%), 18:0 (4.1-8.6\%), 20:5n-3 (13.3$25.6 \%)$ and $22: 6 n-3(8.1-16.7 \%)$ as enumerated in Table 2, as was also observed by Caers et al. and Kochi in the scallop Argopecten purpuratus (9) and the venus shell Phacosoma japonica (10). Major fatty acid compositions were essentially the same for all these species. Many marine species of molluscs are rich in 20:5n-3, with less 22:6n-3 (11). The proportions of 20:5n-3 and 22:6n-3 of TL for M. venulosus and M. zyonoensis differed significantly. In all tissues, $M$. venulosus was a higher in 22:6n-3 than in M. zyonoensis, whereas $M$. zyonoensis had more 20:5n-3 than M. venulosus. The proportion of $20: 5 n-3$ was more abundant in viscera than other tissues in these two species. The proportions of n-3 polyunsaturated fatty acids (PUFA) were particularly high in muscle tissue for $M$. venulosus and $M$. zyonoensis, at 41.1 and $44.1 \%$, respectively. The proportions of n-3 and n- 6 PUFA were richly present in muscle tissue, constituting nearly $50 \%$ of total fatty acids. In viscera from $M$. zyonoensis, 16:1n-7 was much greater than in any other tissue with, the minimum amount being 18:0.

Minor branched saturated fatty acids found were 4,8,12-methyltridecanoic (TMTD), phytanic (PA), 15methylhexadecanoic (iso 17:0), 16-methylheptadecanoic (iso 18:0) and 17-methyloctadecanoic acids (iso 19:0). Odd-chain saturated fatty acids were pentadecanoic (15:0), heptadecanoic (17:0) and nonadecanoic acids (19:0). PA was present in all tissues, but TMTD could be found only in the viscera tissue of either species in small amounts (M. venulosus and $M$. zyonoensis, at 1.9 and $2.2 \%$, respectively). PA and TMTD were produced via the degradation of dietary chlorophyll, as already reported for various bivalve molluscs $(11,12)$.

2-Hydroxy fatty acids were identified by GC-MS, as 2-hydroxypentadecanoic (key fragment ions of the methyl ester at $m / z 272[\mathrm{M}]^{+}(8 \%), 213[\mathrm{M}-59]^{+}(86 \%)$,
$103(18 \%)$, and $90(81 \%)), 2$-hydroxyhexadecanoic (key fragment ions at $m / z, 286[\mathrm{M}]^{+}(12 \%), 227[\mathrm{M}-59]^{+}$ (89\%), $103(26 \%)$, and $90(65 \%))$ and 2-hydroxyheptadecanoic acids (key fragment at $\mathrm{m} / \mathrm{z}, 300[\mathrm{M}]^{+}(17 \%)$, $241\left[^{\mathrm{M}-59]^{+}}(95 \%), 103(27 \%)\right.$, and $\left.90(70 \%)\right)$. No other 2-hydroxy fatty acids, possibly owing to having a chain-length greater than $\mathrm{C}_{20}$, could be detected by GC. 2-Hydroxy fatty acids generally derive from sphingolipids which are nervous functions and the structural components of membranes. So far 2-hydroxyhexadecanoic and 2-hydroxyheptadecanoic acids have been shown to be present in some species of mussels according to the literature $(13,14)$. To the best of authors' knowledge, 2-hydroxy fatty acids have been identified in the genus Megangulus for the first time in the present study.

Typical non-methylene interrupted (NMI) fatty acids were detected and determined as 7,15-22:2 and 7,13$22: 2$, the former being present at a high concentration (1.0-6.3\%) in all tissues. These fatty acids are usually present in lipids of many marine invertebrates, such as mussels, oysters and gastropods $(11,16,17)$. The functions of NMI fatty acids are not fully understood; possibly, they may compete with PUFA for the uptake into tissue lipids in marine organisms and act as inhibitors of lipid peroxidation processes in the membranes of marine bivalves $(11,18)$. No other NMI fatty acids could be identified here, owing to the amounts being too small to permit detection.

Aldehydes, which originate from plasmalogens (1-Oalk-1' -enyl-2-acyl glycerophospholipids), mainly present in PL, with chain-lengths of $\mathrm{C}_{16}, \mathrm{C}_{17}, \mathrm{C}_{18}$ and $\mathrm{C}_{20}$ were always found to be present in all tissues (shown in Table 3). Aldehydes were determined and characterized as dimethylacetals (DMAs) by GC-MS. Predominant DMAs were 18:0 DMA and 20:1 DMA, at 50-56\% and $25-34 \%$, respectively. The content of 18:0 DMA was highest in viscera. Except for minor DMA components, the present findings accord well with data for scallop and oyster species, Argopecten purpuratus and Crassostrea gigas, respectively $(9,15)$. In contrast to other marine organisms, the composition of DMA in bivalves is very poorly documented. The components and distribution of DMA in various bivalve tissues as well as its functions may offer clues to understand the response of marine bivalves to environmental stresses (19).

For clarification of the main fatty acid component distribution in NL and PL (mainly PC and PE), fatty 
Table 3 Proportion (\%) of Dimethylacetals Detected in Methanolyzates of Total Lipids in Various Tissues of Megangulus venulosus and Megangulus zyonoensis.

\begin{tabular}{ccccccc}
\hline \multirow{2}{*}{ Dimethylacetal } & \multicolumn{2}{c}{ Mantle } & \multicolumn{2}{c}{ Muscle } & \multicolumn{2}{c}{ Viscera } \\
\cline { 2 - 7 } & M. venulosus & M. zyonoensis & M. venulosus & M. zyonoensis & M. venulosus & M. zyonoensis \\
\hline $16: 0$ & 4.4 & 6.3 & 6.5 & 9.2 & 4.3 & 6.2 \\
$17: 0$ & 6.3 & 5.1 & 6.5 & 4.2 & 6.0 & $<0.1$ \\
$18: 0$ & 51.6 & 53.8 & 50.0 & 50.0 & 56.4 & 56.3 \\
$18: 1$ & 5.7 & 3.2 & 3.3 & 2.5 & 3.4 & 12.5 \\
$20: 0$ & 3.8 & 4.4 & $<0.1$ & $<0.1$ & $<0.1$ & $<0.1$ \\
$20: 1$ & 28.2 & 27.2 & 33.7 & 34.1 & 29.9 & 25.0 \\
\hline
\end{tabular}
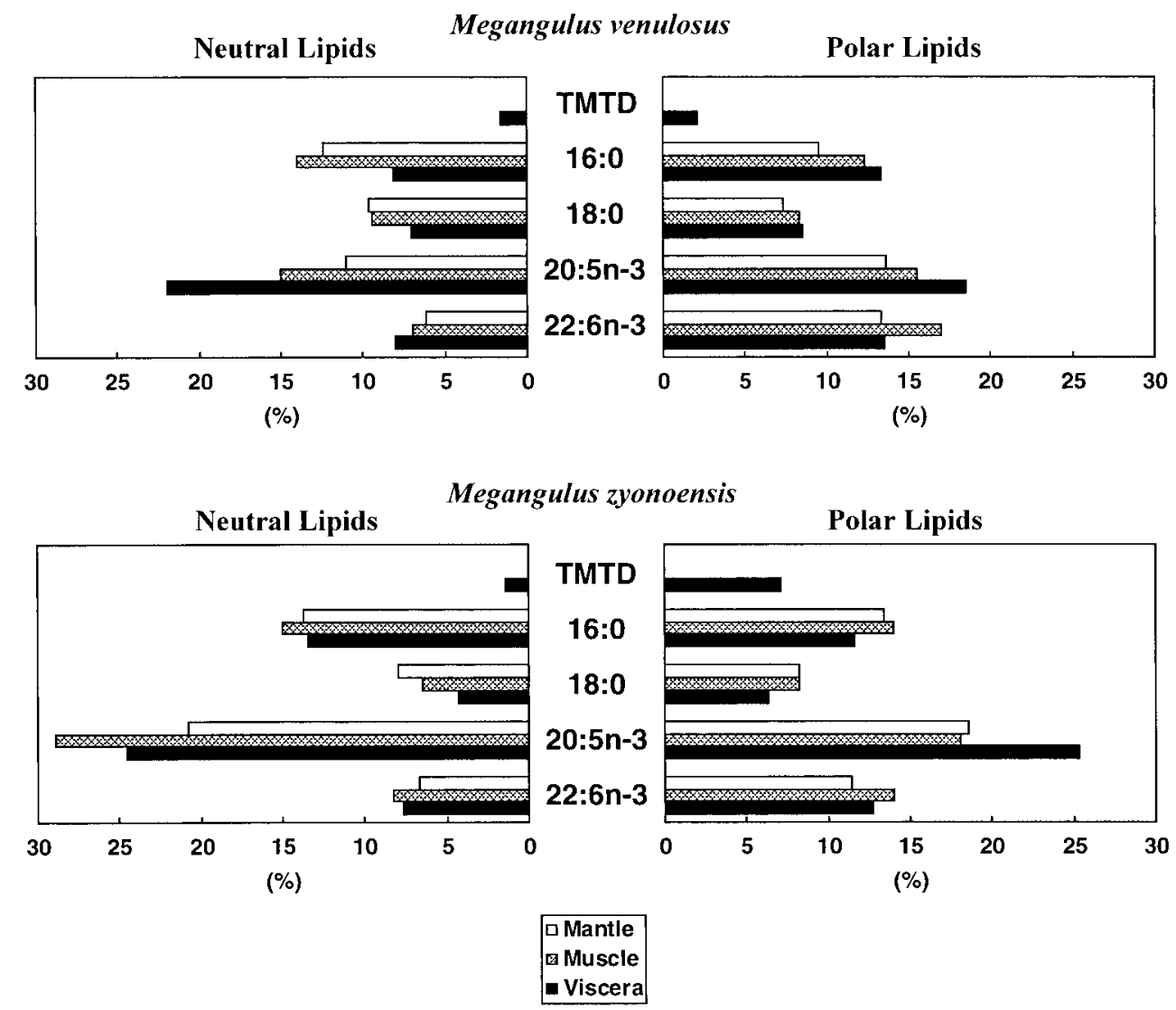

Fig. 1 Comparison of Fatty Acid Components in Neutral and Polar Lipids of Mantle, Muscle and Viscera. 
acids in each lipid fractionated were analyzed for comparison with other tissue lipids, and the these results are shown in Fig. 1. TMTD in PL was found to be higher than in NL in viscera of the two species in this study. One isolated PL in M. zyonoensis was found to contain a very high level of TMTD, as much as $7 \%$ of total fatty acids. TMTD has been observed in considerable amounts in the scallop Argopecten purpuratus and Placopecten magellanicus, mainly in PL and NL (mainly triacylglycerol), respectively, from digestive glands ( 9 , $20)$ and therefore would appear to be a biological marker of food web effects. This is also supported based on determinations of NL and PL fractions from various bivalve tissues. Major fatty acids of PL in either species were 16:0, 20:5n-3 and 22:6n-3, and for NL 16:0 and 20:5n-3. The proportion of 22:6n-3 in NL and PL differed significantly, 22:6n-3 being much higher in PL. The content of 20:5n-3 considerably exceeded that of 22:6n-3 in NL and PL, and 20:5n-3 was highest in $M$. zyonoensis in both fractions. Differences in proportions of n-3, n- 6 PUFA and TMTD of TL in various tissues would therefore appear to be due to difference in NL and PL, as noted in this study.

Fatty acids of M. venulosus and M. zyonoensis were noted here to be similar to those observed in scallop, oyster and mussel species, though various branched saturated fatty $(9,15,18)$ and 2-hydroxy fatty acids $(13,14)$ as minor components have also been shown to be present in some marine bivalves. Fatty acid compositions in the two species were virtually the same. The present study provides basic data on the distribution of major fatty acids in the two species and consequently may lead to a better understanding of the functions of lipids and fatty acids in various organs of these bivalves. The lipid classes and fatty acid compositions of $M$. venulosus and M. zyonoensis, as determined by seasonal variation and the reproductive cycle, should be clarified more precisely through additional research.

\section{Acknowledgments}

The authors thank Mr. H. Sakurai, Hokkaido Central Fisheries Experimental Station, for valuable suggestions on the taxonomy of bivalves, and Professor N. Miyazaki, the University of Tokyo, for encouragement throughout this work. The present work was in part conducted as a cooperative research program with Otsuchi Marine Research Center, Ocean Research Insti- tute, the University of Tokyo.

\section{References}

1. M. KURATA, Megangulus venulosus (Schrenck), Fishes and Marine Invertebrates of Hokkaido: Biology and Fisheries (K. NAGASAWA and M. TORISAWA, ed.), Kita-nippon Kaiyou Center, Sapporo, Hokkaido, pp. 254-255 (1991).

2. S. GOSHIMA, K. NAGAMOTO, K. KAWAI and S. NAKAO, Reproductive Cycle and Growth of the Northern Great Tellin, Megangulus venulosus, in Shiriuchi, Hokkaido, Benthos Res., Vol. 40, 23-33 (1991).

3. R.J. POLLERO, M.E. RÉ and R.R. BRENNER, Seasonal Changes of the Lipids of the Mollusc Chlamys tehuelcha, Comp. Biochem. Physiol., Vol. 64 A, 257-263 (1979).

4. J.-Y. BESNARD, P. LUBET and A. NOUVELOT, Seasonal Variations of the Fatty Acid Content of the Neutral Lipids and Phospholipids in the Female Gonad of Pecten maximus L., Comp. Biochem. Physiol., Vol. 93B, 21-26 (1989).

5. F.-L.E. CHU, K.L. WEBB and J. CHEN, Seasonal Changes of Lipids and Fatty Acids in Oyster Tissues (Crassostrea virginica) and Estuarine Particulate Matter, Comp. Biochem. Physiol., Vol. 95A, 385-391 (1990).

6. E.G. BLIGH and W.J. DYER, A Rapid Method of Total Lipid Extraction and Purification, Can. J. Biochem. Physiol., Vol. 37, 911-917 (1959).

7. W.R. MORRISON and L.M. SMITH, Preparation of Fatty Acid Methyl Esters and Dimethylacetals from Lipids with Boron Fluoride-methanol, J. Lipid Res., Vol. 5, 600-608 (1964).

8. J.C. DITTMER and R.L. LESTER, A Simple, Specific Spray for the Detection of Phospholipids on Thin-layer Chromatograms, $J$. Lipid Res., Vol. 5, 126-127 (1964).

9. M. CAERS, P. COUTTEAU, K. CURE, V. MORALES and G. GAJARDO, The Chilean Scallop Argopecten purpuratus (Lamarck, 1819): I. Fatty Acid Composition and Lipid Content of Six Organs, Comp. Biochem. Physiol., Vol. 123B, 89-96 (1999).

10. M. KOCHI, Fatty Acid Composition of Lipids from Some Marine Shellfishes, J. Shimonoseki Univ. Fish., Vol. 23, 155-162 (1975)

11. J.D. JOSEPH, Distribution and Composition of Lipids in Marine Invertebrates, Marine Biogenic Lipids, Fats, and Oils (R.G. Ackman, ed.) Vol. II, CRC Press. Inc., Boca Raton, Florida, pp. 49-143 (1989).

12. M.V. PIRETTI, F. ZUPPA, G. PAGLIUCA and F. TAIOLI, Investigation of the Seasonal Variations of Fatty Acid Constituents in Selected Tissues of the Bivalve Mollusc Scapharca inaequivalvis (Bruguiére), Comp. Biochem. Physiol., Vol. 89B, 183-187 (1987)

13. J. FANG, P.A. COMET, J.M. BROOKS and T.L. WADE, Nonmethylene-Interrrupted Fatty Acids of Hydrocarbon Seep Mussels: Occurrence and Significance, Comp. Biochem. Physiol., Vol. 104B, 287-291 (1993).

14. K.J. MURPHY, B.D. MOONEY, N.J. MANN, P.D. NICHOLS 
and A.J. SINCLAIR, Lipid, FA, and Sterol Composition of New Zealand Green Lipped Mussel (Perna canaliculus) and Tasmanian Blue Mussel (Mytilus edulis), Lipids, Vol. 37, 587-595 (2002).

15. P. SOUDANT, K.V. RYCKEGHEM, Y. MARTY, J. MOAL, J.F. SAMAIN and P. SORGELOOS, Comparison of the Lipid Class and Fatty Acid Composition between a Reproductive Cycle in Nature and a Standard Hatchery Conditioning of the Pacific Oyster Crassostrea gigas, Comp. Biochem. Physiol., Vol. 123B, 209-222 (1999).

16. J.S. KLINGENSMITH, Distribution of Methylene and Nonmethylene-Interrupted Dienoic Fatty Acids in Polar Lipids and Triacylglycerols of Selected Tissues of the Hardshell Clam (Mercenaria mercenaria), Lipids, Vol. 17, 976-981 (1982).
17. N.V. ZHUKOVA and V.I. SVETASHEV, Non-Methylene-Interrupted Dienoic Fatty Acids in Molluscs from the Sea of Japan, Comp. Biochem. Physiol., Vol. 83B, 643-646 (1986).

18. M. ABAD, C. RUIZ, D. MARTINEZ, G. MOSQUERA and J. SÁNCHEZ, Seasonal Variations of Lipid Classes and Fatty Acids in Flat Oyster, Ostrea edulis, from San Cibran (Galicia, Spain), Comp. Biochem. Physiol., Vol. 110C, 109-118 (1995).

19. S. CHAPELLE, Plasmalogens and $O$-Alkylglycerophospholipids in Aquatic Animals, Comp. Biochem. Physiol., Vol. 88B, 1-6 (1987).

20. G.E. NAPOLITANO and R.G. ACKMAN, Fatty Acid Dynamics in Sea Scallops Placopecten magellanics (Gmelin, 1791) from Georges Bank, Nova Scotia, J. Shell Res., Vol. 12, 267-277 (1993). 